\title{
Ritual Mistis di Dunia Politik: Studi pada Ritual Ngalab Berkah di Gunung Kemukus
}

\section{Fibry Jati Nugroho ${ }^{*}$}

1 Sekolah Tinggi Teologi Sangkakala, Indonesia; e-mail: fibryjatinugroho@gmail.com

* Correspondence

Received: 2020-05-02; Accepted: 2020-05-31; Published: 2020-06-25

\begin{abstract}
Mystical rituals are still very thick in people's lives. Even though the times are modern, rituals in the supernatural are still performed. Community life cannot be separated from mystical rituals, which are then manifested in their spiritual practice. In this study presented a mystical ritual performed by pilgrims who Ngalab Berkah on Gunung Kemukus. Theritual Ngalab Berkah will be used as an object of study in relation to contestation in the political world. By using a qualitative approach and descriptive analysis, it was found that theframe Javanese religious and Max Weber's theory regarding charismatic leadership caused mystical rituals to remain in demand among political contestants. The results of mystical rituals in the form of Ngalab Berkah on Gunung Kemukus, make ritual performers get harmonization between macrocosm and microcosms, charisma as a leader, get pulung (kebegjan), and get wisdom and mercy from Prince Samudra. Mystical rituals carried out by pilgrims proved to be a powerful enough path for political contestants to win their contest in the political world.
\end{abstract}

Keywords: Gunung Kemukus; Javanese Religion; Ngalap Berkah; Ritual; Politics.

\begin{abstract}
Ritual mistis masih sangat kental di dalam kehidupan masyarakat. Meskipun zaman telah modern, namun ritual di alam gaib tetap dilakukan. Kehidupan masyarakat tidak dapat dilepaskan dari ritual mistis, yang kemudian diwujudkan dalam laku spiritualnya. Dalam penelitian ini disajikan ritual mistis yang dilakukan oleh para peziarah yang Ngalab Berkah di Gunung Kemukus. Ritual Ngalab Berkah akan dijadikan sebagai obyek kajian dalam kaitannya dengan kontestasi di dunia politik. Dengan menggunakan pendekatan kualitatif dan analisis deskriptif, ditemukan bahwa frame agama Jawa dan teori Max Weber berkenaan dengan kepemimpinan kharismatik menyebabkan ritual mistis tetap laris di kalangan kontestan politik. Hasil dari ritual mistis yang berupa Ngalab Berkah di Gunung Kemukus, menjadikan pelaku ritual mendapatkan harmonisasi antara makrokosmos dan mikrokosmos, kharisma sebagai pemimpin, mendapat pulung (kebegjan), serta mendapatkan hikmat dan belas kasihan dari Pangeran Samudra. Ritual mistis yang dijalankan oleh para peziarah terbukti sebagai jalan yang cukup ampuh untuk ditempuh para kontestan politik dalam memenangkan kontestasinya di dunia politik.
\end{abstract}

Keywords: agama jawa; gunung kemukus; ngalap berkah; ritual; politik.

\section{Pendahuluan}

Era modernitas yang dibarengi dengan disrupsi dan disparitas struktur sosial, acapkali dibarengi dengan perubahan yang sangat cepat pada berbagai bidang. Informasi yang serba cepat dan instan membuat pengetahuan berkembang secara pesat. Jika di masa lampau gelar Sarjana sudah merupakan sebuah pencapaian yang prestisius, maka di masa sekarang gelar tersebut merupakan sebuah hal yang lumrah. Di tengah arus modernitas dan kemajuan ilmu pengetahuan, secara faktual didapati bahwa dunia mistik tidak dapat ditinggalkan dalam kehidupan masyarakat. 
Kehidupan modern tidak dapat terlepas dari pengaruh dunia mistik di dalamnya. Sebagai contoh, banyak orang modern yang tetap percaya tentang hari baik, dengan menggunakan perhitungan mistik di dalamnya. Penetapan hari baik tersebut biasa dilakukan untuk menghitung hari pernikahan (Oktiasasi \& Harianto, 2016; Yuliana \& Sadewo, 2019), menempati rumah baru (Mujiyah, 2014; Permatasari \& Habsari, 2015) ataupun untuk hari istimewa lainnya. Perhitungan hari baik tersebut, biasanya dipercaya dan digunakan sebagai sarana merawat harmonisasi di semesta.

Di dalam alam pikir tradisional, dunia ini dibagi menjadi dua, yaitu makrokosmos dan mikrokosmos (Sumardjo, 2011). Makrokosmos mempunyai pengertian bahwa alam semesta terdapat kekuatan-kekuatan supranatural (adikodrati), sehingga ia merupakan pusat dari alam semesta. Di dalam makrokosmos, terdapat hirarki yang menandakan tingkatan dari kehidupan manusia. Tingkatan tersebut terdiri dari tiga tingkat, yaitu dunia atas (para dewa), dunia manusia (dunia nyata), dunia bawah (dunia roh jahat). Di dalam dunia manusia itulah yang dikenal dengan mikrokosmos, dimana di dalamnya tercermin pada kehidupan manusia dengan lingkungannya, susunan manusia dalam masyarakat, tata kehidupan manusia sehari-hari dan segala sesuatu yang nampak oleh mata (Endraswara, 2003). Konsep tersebut yang kemudian membuat ritual mistik dipercaya sebagai sarana untuk mengharmonisasikan alam nyata dengan alam yang tidak nyata.

Di tengah paradigma dunia mistik yang ada, tidak dapat dipisahkan dari kehidupan bermasyarakat, termasuk di dalamnya dunia politik. Di dalam kontestasi perebutan "kursi panas" baik untuk legislatif, maupun pemilihan presiden, dunia mistik selalu menjadi salah satu cara yang dipakai untuk memenangi pertarungan tersebut. Apabila menilik perkembangan kepemimpinan di bangsa Indonesia, banyak dari kalangan pejabat negara yang masih memegang kuat dunia mistik di tengah kepemimpinannya. Beberapa upacara dan ritual terlihat jelas dalam pertunjukan wayang di Istana Presiden dengan lakon yang dipilih langsung oleh Presiden Soekarno (Anderson, 1984). Dalam menghadapi krisis Irian Barat pada periode tahun 1960 bahkan putra dari pasangan Ida Ayu Nyoman Rai dan Soekemi Sosrodiharjo melibatkan berbagai tokoh dan kelompok mistik dalam kampanye perebutan Irian Barat dari tangan Belanda. Hal lain yang paling mencolok adalah pendirian Lingga modern dalam bentuk Monumen Nasional (Monas) (Anderson, 1984).

Presiden kedua Bangsa Indonesia juga kerap dikaitkan dengan dunia mistik. Dalam berbagai pemberitaan di media, Presiden Soeharto kerapkali terlihat mengunjungi tempat-tempat sakral yang memiliki kekuatan adikodrati. Presiden Soeharto sangat mempercayai klenik kebatinan Jawa pedalaman yang kental, sebuah klenik yang hanya mengakui Islam dalam bentuk esotoris dan hukum agama hanya memiliki kekuatan kecil. Dalam dunia inilah Soeharto menemukan kedamaian batin yang bisa menjelaskan gaya kepemimpinannya yang berkepala dingin selama bertahun-tahun" (Ricklefs, 2004). Dua pemimpin bangsa ini telah memperlihatkan keakrabannya dengan ritual mistik, dalam menunjang kiprahnya di dunia politik. Di masa sekarang ini, ritual mistis tetap dilakukan oleh sebagai orang guna memenangkan kontestasi di dunia politik.

Ritual untuk mendapatkan "berkah" biasa dikenal dengan istilah "ngalab berkah". Gunung Kemukus biasa menjadi salah satu tujuan yang dijadikan obyek "ngalab berkah" bagi para peziarah. Gunung Kemukus sendiri merupakan tempat yang dikelola oleh Pemerintah Daerah dan dijaga eksistensinya untuk "dijual" produk mistisismenya (Novitasari, 2015). Pun demikian, terdapat ambiguitas di dalam pemaknaan ritual di kalangan penduduk setempat. Namun, masyarakat setempat menerima dengan baik "makna ritual" yang disematkan oleh pengunjung, dengan pertimbangan dari peningkatan ekonomi di dalam masyarakat (Siatawati \& Priyanto, 2015). Pemaknaan masyarakat lokal tersebut terjadi akibat interaksi dengan peziarah, yang membuat ritual menjadi komoditas wisata (Setiawati \& Kuswarno, 2016). Komunikasi ritual tersebut yang menjadi dasar pemahaman etnografi mistisisme di kalangan pelaku ritual dan masyarakat setempat, akhirnya memunculkan fenomena "ngalab berkah" yang disertai dengan laku ritual dengan seks sebagai medianya (Setiawati \& Safitri, 2018).

Dari sudut pandang fenomenologi, Makam Pangeran Samudro di Gunung Kemukus mempunyai fakta obyektif, bahwa apa yang diminta oleh para pelaku ritual dapat terwujud dan terkabul. Baik yang berkeinginan mendapat penglaris, jodoh, kedudukan ataupun charisma (Subagyo; Muridjal, 2013). 
Motivasi untuk mendapat kekayaan, jabatan dan jodoh menjadi penggerak peziarah melakukan ritual di Gunung Kemukus (Sularno, 2017). Terkait dengan kekuasaan dan jabatan, hasil penelitian Indah Ambar Sari, menyatakan bahwa pada dasarnya politik dan spiritualitas sangat erat kaitannya. Para elit kekuasaan, seringkali memakai mistik Kejawen untuk mendapat dan melanggengkan kekuasaannya (Sari, Indah Ambar; Azhar, 2016). Bagaimana ritual mistis tersebut berperan dalam dunia politik? Tulisan ini akan membahas lebih lanjut terkait ritual mistis di dunia politik.

\section{Metode Penelitian}

Dalam penelitian ini digunakan pendekatan kualitatif dengan metode deskriptif analisis. Menurut Sugiyono, penelitian Deskriptif merupakan penelitian yang dilakukan untuk mengetahui nilai variabel mandiri, baik satu variabel atau lebih (independen) tanpa membuat perbandingan atau dengan menghubungkan antara variabel yang satu dengan variabel yang lainnya. Jenis metode ini digunakan untuk menyajikan data secara menyeluruh dan mendalam terkait dengan interpretasi simbol-simbol dan obyek penelitian di dalam masyarakat (Sugiyono, 2012). Obyek kajian dalam penelitian ini meliputi ritual mistis di Obyek Wisata Religi Gunung Kemukus, khususnya dalam kaitannya dengan kontestasi di dunia politik. Data yang dikumpulkan berupa data kualitatif, berupa hasil observasi, hasil wawancara dan juga dokumentasi terkait ritual di obyek penelitian. Adapun narasumber yang akan diwawancarai meliputi Dinas Pariwisata sebagai pengelola Obyek Wisata, Juru Kunci, Peziarah dan Penduduk setempat. Data yang diperoleh kemudian akan dianalisis menggunakan analisis deskriptif.

\section{Kosmologi dan Ritual Jawa}

\section{Konsep Tuhan dalam Agama Jawa}

Tuhan secara umum dikonsepsikan sebagai yang transenden. Dalam bahasa Inggris, kata tersebut mempunyai arti menembus, teramat sangat. Secara maknawi, Tuhan dipandang sebagai sosok yang mutlak, yang ada sebelum adanya alam semesta, yang supranatural dan yang mengatur jagad semesta. Agama Jawa selalu meyakini ada penguasa alam semesta, yang apabila dikuasai, diadaptasi dalam kehidupan akan mendatangkan berkah (Endraswara, 2015a). Dalam agama Jawa, Tuhan dikonsepsikan sebagai karib yang istimewa, yang diyakini selalu ada dalam setiap keberadaan manusia. Tuhan ditempatkan di posisi super, misterius, di atas kekuatan manusia. Tuhan adalah pengatur hidup, hanya dengan batin, manusia dapat melukiskan apa saja tentang Tuhan (Endraswara, 2011).

Agama Jawa mengkonsepsikan bahwa wahyu diturunkan dari para dewa yang menguasai alam semesta, dan berfungsi untuk menenangkan hidup. Konteks agama Jawa, wahyu sangat dekat dengan pulung (merupakan penanda mendapat keberuntungan dari Yang Ilahi), dan tidak dapat lepas dari konsep begja (keberuntungan). Agama Jawa selalu mengedepankan Kawruh Begja, yang datang dari Kang Gawe Urip (Endraswara, 2015a). Wahyu yang dianggap berasal dari para dewa, yang perlu diraih dengan Laku (perilaku) dan negosiasi. Laku ini cenderung mengarah kepada dunia gaib atau alam gaib, yang didalamnya akan didapati kekuatan gaib atau kekuatan sakti. Dengan keyakinan akan adanya dunia adikodrati, agama Jawa mencirikan adanya kekaguman akan hal-hal atau peristiwa gaib, yang tak dapat diterangkan oleh akal, namun dapat dirasakan dan diyakini di dalam kehidupannya. Keyakinan akan hal yang gaib kemudian memunculkan mitos dan simbol yang dipercaya sebagai perwujudan dari dunia gaib tersebut. Mitos yang berkembang di agama Jawa sangat bervariasi, bergantung dengan kultur, lokasi dan kondisi masyarakat. Sebagai contoh, masyarakat petani meyakini mitos Dewi Sri sebagai dewi kesuburan, sehingga di akhir panen senantiasa diadakan acara slametan sebagai rasa syukur kepada Sang Dewi, karena sudah memberikan berkah kesuburan. Mitos agama Jawa yang bervariasi, bukan mengaburkan kepercayaan masyarakat, justru mempertebal keyakinan. Mitos menghidupkan suasana kebatinan dan memberikan rasa ketenangan di dalamnya. Keyakinan akan sesuatu yang gaib tersebut, kemudian memunculkan kekaguman dan tindakan upacara ritual di dalamnya. 


\section{Ritual dalam Agama Jawa}

Dalam menjalankan laku ritualnya, agama Jawa mempunyai falsafah (Endraswara, 2015b) :

1. Falsafah metafisika, yakni bahwa Tuhan adalah sangkan paraning dumadi.

2. Epistemologi, yaitu proses memperoleh pengetahuan dengan jalan mencapai kesadaran cipta, rasa, dan karsa (hening), kesadaran panca indera, kesadaran pribadi dan kesadaran illahi.

3. Falsafah aksiologi, terkait dengan nilai etik dan estetis.

4. Falsafah anthropologia yaitu pola pikir Jawa yang berkisah tentang persoalan manusia.

5. Falsafah ontologia dan metafisika, yaitu pengalaman yang pernah sungguh-sungguh dialami, dirasakan, dihayati dan bukan sekedar konsep saja.

Dari falsafah yang dihidupi oleh agama Jawa, memunculkan upacara ritual sebagai laku spiritualnya. Sebagai media dalam menjalankan ritual dan menghubungkan dengan dunia gaib, sesaji dipakai sebagai simbol dan langkah negosiasi dengan hal-hal gaib. Kalau orang Jawa tidak mampu memberikan sesaji, muncul perasaan adanya nuansa hidup yang lepas dan belum lengkap. Oleh sebab itu, dalam setiap jengkal kehidupan, orang Jawa senantiasa mempertahankan sesaji sebagai sarana bernegosiasi dengan hal-hal gaib (Endraswara, 2015a).

Agama Jawa menggariskan fungsi sesaji sebagai (Endraswara, 2015a) :

1. Langkah negosiasi spiritual dengan kekuatan adikodrati, agar tidak mengganggu.

2. Pemberian berkah kepada warga sekitar, agar ikut merasakan hikmah sesaji.

3. Perwujudan keikhlasan diri, berkorban kepada Kang Gawe Urip (Sang Pemberi Hidup)

4. Bentuk ucapan terima kasih.

Fungsi sesaji tersebut merupakan cerminan dari naluri keagamaan dari orang Jawa. Dalam konsepnya, sesaji inilah yang menghubungkan antara dunia yang hidup dengan dunia yang tak hidup, atau antara makrokosmos dengan mikrokosmos. Sesaji inilah yang difungsikan untuk menyelaraskan dari dua dunia yang nyata dan tak kasat mata. Pemberian sesaji ini kemudian diyakini dunia gaib akan memberikan bekal, solusi dan kesaktian dalam menjalani hidup di dunia nyata.

Sesaji biasanya akan diberikan di tempat yang diyakini mempunyai kekuatan gaib atau penghubung antara dunia nyata dengan dunia gaib. Dalam kosmologi Jawa, salah satu tempat yang dipercaya dapat menghubungkan yang natural dengan supranatural terletak di makam (kuburan). Makam diyakini sebagai penghubung antara dunia nyata dengan dunia gaib (alam roh). Orang yang telah di makamkan akan menjadi sarana untuk menyambungkan orang yang masih hidup dengan dunia gaib. Oleh sebab itu, banyak orang Jawa memberikan sesaji di makam, untuk menjaga ketenangan di alam gaib. Agama Jawa meyakini apabila alam nyata mengalami kekacauan, disebabkan karena alam gaib mengalami kekacauan juga.

Dalam bentuk yang lain, sesaji diberikan sebagai perwujudan syukur atas panen atau setelah melewati masa liminal kehidupan. Dalam keyakinan Jawa, sesaji yang diberikan dalam bentuk slametan diwujudkan dalam bentuk tumpeng dan ambengan. Sesaji ini biasanya diberikan dalam ritual kesuburan maupun terkait upacara perkawinan. Tumpeng berbentuk kerucut, dengan puncak kerucut di atasnya. Ambengan berbentuk lebih pendek dan tidak berujung runcing. Simbolisasi tumpeng dan ambengan ini merupakan pemahaman serta metafora dari lingga dan yoni yang diyakini sebagai lambang kesuburan. Di sisi yang lain, pemaknaan simbol ini terkait dengan simbol laki-laki dan perempuan. Tumpeng sebagai simbol laki-laki (lingga) dan ambengan sebagai simbol putri (yoni) (Endraswara, 2015a). Dimensi lelaki dan perempuan senantiasa dimunculkan dalam simbol kesuburan.

Simbolisme yang dipakai dalam ritual di agama Jawa sedikit banyak mengacu kepada ajaran Tantraisme Hindu. Tantraisme atau ada yang menyebut dengan Tantrisme, merupakan ajaran yang mengembangkan pemujaan terhadap Dewi Ibu atau Dewi Kemakmuran. Ajaran Tantra sendiri terutama berkaitan dengan praktik-praktik spiritual dan bentuk-bentuk ritual ibadah yang bertujuan pada pembebasan dari kebodohan dan kelahiran kembali, alam semesta yang dianggap sebagai permainan ilahi Shakti dan Siwa. Dalam "kidal" Tantra (Vamachara), ritual hubungan seksual 
digunakan sebagai cara untuk masuk ke dalam proses yang mendasari dan struktur alam semesta (Lorens, 2000).

Tantraisme diejawantahkan ke dalam simbol di tempat sucinya. Dewasa ini hampir di semua tempat suci (Pura) dapat dilihat Siwalingga yang diwujudkan dengan lingga - yoni. Menurut ajarannya, itu melambangkan ruang di mana alam semesta menciptakan dan melenyapkan dirinya berulang-kali. Tantra mewujudkannya dengan phalus dan yoni sebagai perlambang dari sifat laki-laki dan wanita. Ia juga melambangkan prinsip-prinsip kreatif dari kehidupan. Secara filosofis, simbolisme lingga yoni bersifat Chala (bergerak) atau Achala (tidak bergerak). Chala Lingga dapat ditempatkan di Pura atau rumah atau dapat dibuat secara sementara dari tanah liat atau adonan atau nasi. Achala Linga biasanya ditempatkan di Pura, terbuat dari batu. Bagian terbawah dari Siwalingga disebut Brahmabhaga yang melambangkan Brahma, bagian tengah yang berbentuk segi delapan disebut Wishnubhaga yang melambangkan Wishnu, dan bagian menonjol yang berbentuk silinder disebut Rudrabhaga, serta pemujaan kepadanya disebut Pujabhaga (Yeshe, 2001).

Dalam perkembangannya, tantra sering menggunakan simbol-simbol material termasuk simboksimbol erotis, sehingga tantra sering kali diidentikkan dengan ajaran kiri yang mengajarkan pemenuhan nafsu seksual, pembunuhan dan kepuasan makan daging. Padahal beberapa perguruan tantra yang saat ini mempopulerkan diri sebagai tantra putih menjadikan pantangan mabuk-mabukan, makan daging dan hubungan seksual sebagai sadhana dasar dalam meniti jalan tantra. Laku seksual yang dikembangkan merupakan perwujudan sebagai ketaatan dengan doktrinnya. Ajaran Tantraisme kemudian yang berkembang pula di dalam tradisi agama Jawa.

Dalam berbagai ritual agama Jawa, konsep laki-laki dan perempuan senantiasa dimunculkan sebagai simbol keseimbangan ciptaan, simbol kesuburan, simbol kesatuan dan simbol kesucian, sebagaimana yang dikonsepsikan ke dalam ajaran Tantraisme. Acapkali simbol kesuburan dan kesaktian terletak pada hubungan laki-laki dan perempuan. Dalam falsafah hidup orang Jawa, yang dimunculkan melalui tokoh pewayangan, kesaktian seseorang dimunculkan dalam tokoh Arjuna. Falsafah madya yang memunculkan konsep bahwa Arjuna adalah lelananging Jagad, yang paling sakti di antara para ksatria sejamannya. Dalam kerabat Pandawa ada yang disebut pamadyaning pandawa, yakni Arjuna. Satria ini berada di tengah-tengah. Ia lambang kesaktian, karena bisa menguasai banyak wanita. Baginya, wanita adalah simbol kesaktian. Modus operandi ihwal kesaktiannya adalah karena Arjuna bisa menahlukan madya (tengah). Yakni bagian fisik manusia yang berada di tengah (phalus dan vagina). Tempat rasa sejati yang sulit digambarkan. Jika kedua (tengah ketemu tengah) dalam arti telah manunggal, maka hidup manusia akan tenang. Itulah sebabnya, kenikmatan hidup manusia Jawa berada di tengah (madya), bukan di bagian atas dan bawah. Hidup menjadi kurang, jika belum menikmati kenikmatan sejati (madya) (Endraswara, 2015b).

Keyakinan akan pengisahan kesaktian Arjuna menjadikan hubungan laki-laki dan perempuan sebagai perwujudan ritual kesaktian, kesuburan dan keberkahan. Dari keyakinan ini, hubungan seksual laki-laki dan perempuan mewarnai mitologi Jawa, sebagai puncak ketenangan, kesenangan dan sumber kesaktian. Ketika manusia mengalami tekanan kehidupan, hubungan seksual dapat menjadi sumber mencari ketenangan kehidupan. Dari keyakinan ini, menilik sejarah Raja-Raja Jawa, maka perempuan menjadi salah satu indikator kekuatan dan kesaktiannya. Hubungan seks antara lakilaki dan perempuan diyakini dapat menjadi puncak untuk mendekatkan diri kepada ketenangan di alam lain. Kosmologi yang terbentuk menjadikan seks sebagai ritual untuk dapat menarik berkah, ketenangan, kesaktian dan kesuburan dari Alam lain. Tidak heran, dalam berbagai ritual yang berbasis kosmologi Jawa, ritual seks menjadi salah satu wujud untuk mendapat keberkahan dan ketenangan di dunianya, karena seks dianggap sebagai sesuatu yang sakral dan sebagai sarana untuk dapat bertemu dengan Tuhan.

\section{Ritual Sebagai Tindakan Sosial}

Dalam pandangan Max Weber, tindakan-tindakan keagamaan merupakan sebuah tindakan sosial di dalam masyarakat. Dalam pemahamannya, tindakan sosial berorientasi kepada nilai tertentu, termasuk nilai keagamaan. Weber menginterpretasikan tindakan keagamaan dengan memahami 
motif-motif sang aktor dari sudut pandang subyektif (Furseth, 2006). Weber tidak secara spesifik membicarakan tentang esensi agama. Namun, ia lebih menelaah kepada kondisi dan dampak dari agama yang berhubungan erat dengan aksi/tindakan sosialnya. Diskursus ini didapat dari pemahaman penganut agama yang tercermin di dalam perilaku keagamaannya, pengalaman, ide dan tujuan dari individu tersebut. Penganut agama pada masa awal percaya kepada kharisma pada pemimpinnya. Pemimpin yang mempunyai kharisma dianggap sebagai orang yang mempunyai anugrah dari Tuhan. Fenomena religius ini yang masih menjadi agama rakyat (Weber, 1978).

Sebuah proses abstraksi tentang pemahaman agama primitif menyebutkan, bahwa ada banyak benda yang mempunyai kharisma atau kekuatan baik berupa binatang, artefak maupun orang. Bendabenda tersebut merupakan sebuah penghantar visible sebagai sebuah entitas tentang Tuhan. Selanjutnya, Roh dan Setan mulai di-visible-kan oleh manusia sebagai pengejawantahannya. Kharisma dari Tuhan yang diturunkan kepada manusia nampak pada para magician yang mempunyai kekuatan khusus yang berbeda dari manusia lainnya. Magician (ahli magis) ini yang mempunyai kekuatan/kharisma tetap untuk dapat memunculkan kekuatan-kekuatan gaib (Weber, 1978). Berdasarkan kekuatan gaib inilah tindakan sosial masyarakat mulai berubah. Bagi Weber, tindakan sosial masyarakat merupakan hasil abstraksi dan rasionalisasi terhadap pengalaman-pengalaman hidupnya, termasuk cara beragama.

Weber menyebutkan, tentang adanya perbedaan antara tuntutan gaib dengan permohonan, berdoa dan berkorban. Melalui doa (usaha rasionalis) disampaikanlah permohonan supaya para dewa memberikan hal-hal ajaib atas doa dan permohonan mereka, hal ini memiliki kesamaan dengan bisnis murni, adanya harapan imbalan. Melaui pengorbanan (mempersembahkan korban khususnya binatang) sebagai media untuk memaksa para dewa supaya memberikan permohonan/memberikan imbalan. Melalui ritus pengorbanan ini menciptakan komunitas persaudaraan dengan makan secara bersama-sama. Persaudaraan bukan saja diantara orang-orang yang mempersembahkan korban tetapi juga bersama dewa (tuhan) (Weber, 1978).

\section{Ritual di Obyek Wisata Religi Gunung Kemukus}

Di Jawa Tengah, banyak dijumpai masyarakat yang masih melakukan tradisi turun temurun yang berasal dari nenek moyangnya, sebagai sui generis masyarakat. Salah satu yang menarik adalah masyarakat di daerah Desa Pendem, Gemolong, Kabupaten Sragen yang masih percaya dengan adanya ngalab berkah dengan cara mengadakan ritual-ritual khusus untuk mendapatkan rejeki ataupun kharisma yang instan dan cepat. Mereka mengadakan ritual dan percaya kepada ritus Makam Keramat Pangeran Samudra dan Dewi Ontrowulan.

Lokasi ritus makam keramat tersebut dikenal dengan sebutan Gunung Kumukus. Lokasi dan cara ritual yang seksi, berdaya magis tinggi untuk menarik minat ratusan ribu peziarah setiap tahunnya. Secara geografis, Gunung Kumukus lebih patut dijuluki sebagai bukit karena ketinggiannya hanya 300 meter. Di puncak bukit ini terletak makam Pangeran Samudro dan kekasih, sekaligus ibunya Dewi Ontrowulan serta tujuh makam pengiringnya dan kudanya yang juga dianggap sebagai tempat-tempat keramat. Peziarah berbondong-bondong berdatangan dari berbagai sudut Indonesia menggunakan angkutan umum, mobil pribadi atau sewaan. Untuk mencapai daerah ini tidak begitu susah. Gunung Kumukus terletak $30 \mathrm{~km}$ sebelah utara Solo di jalan arah ke Purwodadi. Gunung Kumukus di kelilingi ladang tebu, jagung dan singkong, di mana penduduk asli mendapatkan sebagian pemasukan mereka. Sebagian besar pemasukan masyarakat (khususnya penghuni baru) diambil dari perekonomian yang berkembang akibat kedatangan ribuan pengunjung setiap bulan

Berjubelnya para peziarah yang memadati Gunung Kemukus, membuat pemerintah melirik tempat ini untuk dijadikan obyek wisata spiritual. Berdasarkan data obyek wisata dari Dinas Kebudayaan dan Pariwisata Jawa Tengah, Gunung Kemukus tidak masuk dalam daftar pariwisata di Jawa Tengah. Namun, di Kabupaten Sragen, obyek wisata spiritual ini menjadi primadona pemasukan pemerintah di sektor pariwisata, di samping obyek wisata edukasi arkeologi Sangiran (Aribowo, 2017). Obyek wisata spiritual ini dilandaskan pada perkembangan dari sebuah cerita tentang Pangeran Samudro yang dianggap sebagai tokoh berkekuatan supranatural. Kekuatan supranatural tersebut 
mampu mengabulkan semua cita-cita dan keinginan para peziarah yang berdatangan ke makamnya dalam rangka ngalap berkah. Namun, kekuatan tersebut ini akan terwujud jika peziarah berhubungan seks dengan lawan jenisnya, khususnya yang laki-laki atau perempuan yang bukan muhrimnya. Ritual ini harus dilakukan sebanyak 7 kali berturut-turut sesuai dengan pasarannya, khususnya Jumat Pon dan Jumat Kliwon.

Ketika dirunut, mitos tersebut terbagi ke dalam tiga versi. Adapun versi tersebut adalah :

\section{Mitos versi Pemerintah}

Pemerintah Daerah Kabupaten Dati II Sragen memandang perlu menerbitkan buku sebagai pedoman bagi para peziarah tentang mitos Pangeran Samudro di Gunung Kemukus. Buku ini dikeluarkan oleh Dinas Pariwisata Daerah Kabupaten Dati II Sragen. Pemerintah memandang perlu meluruskan kisah Pangeran Samudro dikarenakan kisah yang selama ini diyakini oleh peziarah dan masyarakat setempat itu tidak benar dan terlihat menyimpang. Disamping itu, diharapan para pengunjung dan peziarah tidak salah pengertian dan salah langkah dalam melaksanakan ziarah. Kisah yang dibuat pemerintah adalah sebagai berikut (Ahmad, 2017).

Pada waktu Kerajaan Majapahit runtuh pada tahun 1478, berdirilah Kerajaan Demak dan yang menjadi raja adalah Raden Patah, putra raja Majapahit terakhir yang lahir dari istri selir. Menjelang jatuhnya Kerajaan Majapahit, keluarga putra-putra raja banyak yang melarikan diri keluar dari istana. Pangeran Samudro beserta ibunya yang bernama Raden Ajeng Ontowulan (R.A Kenter) tidak ikut melarikan diri. Mereka berdua diboyong oleh Raden Patah ke Demak. Pangeran Samudro adalah salah seorang pemuda yang baik hati, cerdas, ramah, pendamai, dan penuh tanggung jawab. Sifat-sifat ini diketahui oleh Raden Patah dan beliau ingin memanfaatkan adiknya itu untuk kepentingan Kerajaan Demak. Pada suatu hari Pangeran Samudro dipanggil oleh Raden Patah dan diberi mandat, yakni Pangeran Samudro diutus mencari dan menemui saudara-saudaranya yang telah melarikan diri dan belum diketahui dimana mereka bersembunyi untuk disadarkan, mengakui Kerajaan Demak, dan tidak memusuhinya.

Maksud Raden Patah dapat dibenarkan oleh Pangeran Samudro. Perintahnya diterima dengan senang hati dan dilaksanakannya sekalipun sangat sulit dan berat. Dapat dibayangkan mencari orang yang tersebar letaknya dan tidak diketahui keberadaannya serta harus melewati hutan, gunung, bukit, lembah. Setelah mendapat petunjuk dari Raden Patah dan restu dari ibunya, berangkatlah Pangeran Samudro dengan diikuti oleh dua orang abdi yang setia. Dalam melakukan tugas mulia itu, terdapat banyak sekali rintangan, halangan, ancaman, dan lainnya.Ia sering kepayahan, tidur di hutan, istirahat di rumah penduduk. Hingga saat ini, tempat yang dipakai Pangeran Samudro beristirahat diberi nama sesuai dengan peristiwa yang dialami Pangeran Samudro.

Misalnya, Punden Pondok yang dipakai mondok Pangeran Samudro, Punden Salahan yang ketika itu Pangeran Samudro melakukan kesalahan, Bagorame, dan sebagainya. Pencarian dan penggembaraan itu berjalan bertahun-tahun dan berkat kegigihan Pangeran Samudro tugas tersebut berhasil dilaksanakan. Saudara-saudaranya bersembunyi diberbagai tempat, mereka saling berjauhan tetapi dapat ditemui dan didamaikan.Saudara-saudaranya lalu mengakui bahwa Raden Patahlah yang menjadi Raja di Kerajaan Demak.

Setelah usahanya dirasa berhasil dan sudah meninggalkan ibunya di Demak, Pangeran Samudro pun kembali ke Demak dengan tujuan untuk memberi laporan kepada kakaknya yaitu Raden Patah dan terus menghadap ibunya yang ia hormati dan ia sayangi. Tetapi dalam perjalanan pulang, Pangeran Samudro jatuh sakit. Sampai di Dusun Barong sakitnya bertambah parah dan tidak lagi bisa melanjutkan perjalanan ke Demak. Kemudian Pangeran Samudro mondok di Dukuh tersebut, dan ia memberi perintah kepada dua abdinya supaya melanjutkan perjalanan ke Demak dan melaporkan hasil tugasnya dan memberitahukan keadaan Pangeran Samudro yang sedang jatuh sakit. Dalam keadaan sakit, Pangeran Samudro dirawat oleh penduduk setempat.Akan tetapi penyakitnya makin parah dan Pangeran Samudro merasa bahwa ajalnya makin dekat. Pangeran Samudro memberi pesan kepada penduduk setempat, kalau ia meninggal supaya dimakamkan di puncak Gunung Kemukus di sebelah barat Dusun Barong. 
R.A Ontowulan yang telah bertahun-tahun tidak bertemu dengan puteranya mendapat laporan bahwa puteranya sakit keras dan berada ditempat yang jauh. Begitu mendapat laporan, hatinya menjadi hancur dan sangat kuatir maka dengan hati yang hancur berangkatlah Ontowulan bersama dengan dua abdi Pangeran Samudro tersebut ke Dusun Barong dengan harapan bertemu dengan puteranya. Setelah sampai di dusun Barong, Ontowulan mendapat kabar bahwa Pangeran Samudro meninggal dan dimakamkan di puncak Gunung Kemukus. Sebelum Ontowulan mendaki Gunung Kemukus, dengan rasa sedih ia menyucikan dirinya di sendang yang digunakan untuk memandikan jenasah Pangeran Samudro. Setelah menyucikan dirinya,naiklah ia ke puncak Gunung Kemukus untuk melihat jenasah puteranya. Begitu sampai di atas dan dilihatnya wajah puteranya yang sudah berada diliang kubur bergejolaklah hatinya dan ia berkata bahwa ia ingin mati juga dan dikuburkan satu liang dengan puteranya. Maka saat itu juga berhentilah jantungnya dan ia meninggal disisi jenasah puteranya. Sesuai dengan pesannya, R.A Ontowulan dikubur di satu liang dengan Pangeran Samudro.

Kedua pengikutnya dengan setia menunggui makam tersebut dan mereka bernazar bahwa kelak ketika mereka meninggal, mereka juga ingin dimakamkan berdampingan dengan makam Pangeran Samudro sebagai bukti kesetiaannya dan niat itu terwujud, mereka dimakamkan dekat makam Pangeran Samudro. Keajaiban terjadi yaitu di tempat tersebut dengan tumbuhnya pohon-pohon besar yang menjadikan makam tersebut menjadi sejuk dan rindang serta mempunyai pemandangan yang indah sehingga tempat tersebut dinamakan Gunung Kemukus dan sendangnya diberi nama sendang Ontowulan.

Dari cerita di atas, muncul penafsiran tentang Pangeran Samudro yang begitu dihormati karena ada semacam kepercayaan bahwa makam dari bangsawan yang berjasa untuk Negara mempunyai pengaruh yang sangat baik bagi peziarah yang datang kesana karena Pangeran Samudro adalah sosok pribadi yang bertakwa kepada Tuhan, menghormati orang tua, loyal kepada pemimpin, bertanggung jawab, tidak takut bahaya. Para peziarah mengenang kembali keistimewaan Pangeran Samudro.

\section{Mitos versi peziarah}

Menurut penuturan salah satu peziarah (Bedjo, 2017), Pangeran Samudro adalah putera Raden Patah yang mempunyai karakter tidak terhormat. Ketika ia masih tinggal di istana ayahnya, ia jatuh cinta kepada ibunya dan cintanya tersebut diterima oleh ibunya. Raden Patah mengetahui hubungan tersebut dan Pangeran Samudro dikejar sampai ke Gunung Kemukus.

Di lain pihak, R.A Ontowulan menjadi tergila-gila terhadap anaknya sendiri oleh karena itu ia meninggalkan Demak dan mencari anaknya kemudian terjadilah suatu pertemuan yang menyedihkan. Karena Ontowulan sudah bertemu dengan Pangeran Samudro, untuk melepas kerinduan hatinya mereka melakukan hubungan badan yang seharusnya tidak boleh dilakukan oleh ibu dan anak.Sementara itu datanglah utusan Raden Patah untuk membunuh Pangeran Samudro.Dan terjadilah perkelahian antara Pangeran Samudro dengan para utusan Kerajaan. Sebelum meninggal, Pangeran Samudro berucap:

sing sapa duwe panjangka, marang samubarang kang dikarepake bisane kelakon iku, kudu sarono

pawitan temen, manteb kanthi ati suci, aja slewing-sleweng, kudu mung mandheng marang kang katuju, cedhakno demene koyo dene yen arep nekani marang panggonane dhemenane(Ahmad, 2017).

[barangsiapa mempunyai cita-cita atau keinginan untuk mendapatkannya harus dengan cara yang sungguh-sungguh, mantab, teguh pendirian, dan dengan hati yang suci. Jangan tergoda apapun, harus berkonsentrasi pada yang dituju atau yang diinginkan. Dekatkan apa yang menjadi kesenangannya, seperti akan mengunjungi wanita atau pria idaman lain].

Menurut keyakinan peziarah, Pangeran Samudro adalah orang yang mempunyai ilmu yang tinggi. Ia mendapat kekuatan tersebut dengan cara bertapa. Menurut keyakinan peziarah, datang ke Gunung Kemukus sebanyak tujuh kali dan melakukan hubungan seksual yang bukan pasangannya adalah sebuah langkah penting untuk ngalap berkah karena hal inilah yang diinginkan Pangeran Samudro. Jumlah tujuh kali ini timbul karena ada pengalaman bahwa jumlah ini dapat membawa hasil dan rejeki tersendiri. 
Mitos versi penduduk asli setempat

Dalam versi masyarakat setempat, Pangeran Samudro melarikan diri dari serbuan balatentara Kerajaan Demak dan dia melambangkan kesengsaraan serta ketertindasan masyarakat yang mengalami perubahan besar-besaran setelah Kerajaan Majapahit runtuh. Menurut informasi dari penduduk sekitar, Pangeran Samudro adalah putera tertua dari istri resmi Prabu Brawijaya dari Kerajaan Majapahit. Ketika menginjak remaja, ia dilepaskan ke dunia luar dengan tujuan untuk mengumpulkan pengalaman yang akan berguna di kemudian hari. Setelah beberapa tahun, ia pulang dan jatuh cinta kepada R.A Ontowulan salah seorang selir ayahnya. Cinta ini diterima dengan sangat antusias oleh R.A Ontowulan. Ketika Prabu Brawijaya mengetahuinya beliau sangat marah dan mengusir mereka berdua. Sebelum menetap di Gunung Kemukus mereka mengembara di daerah Sumber Lawang dan mereka menamai beberapa tempat.

Di Gunung Kemukus tinggallah mereka dengan bahagia sebagai suami istri. Tempat yang menjadi kesenangan R.A Ontowulan adalah di sebuah sumber air yang terletak di kaki gunung dan saat ini dikenal orang sebagai sendang Ontowulan. Di sendang tersebut,ia melakukan meditasi selama berharihari. Diceritakan pula jika setiap Ontowulan menggoyangkan rambutnya yang panjang dan diikat dengan bunga, bunga yang jatuh dari rambutnya tumbuh pohon-pohon yang tinggi dan membentuk hutan.

Pada suatu ketika, Ontrowulan pergi bermeditasi di suatu tempat, Pangeran Samudro jatuh sakit dan meninggal dunia. Oleh penduduk desa Barong, jenasahnya dimandikan di sendang dan dimakamkan. Ontrowulan tidak mengetahui hal tersebut. Ketika ia pulang dan mandi disendang untuk kembali menemui suaminya, namun yang dijumpai adalah orang-orang desa yang berkerumun untuk menguburkan Pangeran Samudro, maka sangat sedihlah ia dan Ontrowulan meninggal saat itu juga. Pada suatu hari setelah kejadian ini berlangsung, Pangeran Samudro mendatangi orang tertua di desa dalam suatu penglihatan. Pangeran Samudro mengatakan bahwa ia akan memenuhi semua keinginan setiap orang yang datang kekuburnya dengan membawa bunga. Syaratnya ialah bahwa orang yang datang itu harus memberikan kesan telah mempunyai pacar (Suparno, 2017).

Beredarnya beragam versi mitos tersebut menambah ketidakpastian akan kebenaran yang terjadi dibalik misteri Pangeran Samudro dan Dewi Ontrowulan. Terlepas dari beragam mitos benar atau salah, secara empiris dapat dilihat bahwa banyak orang berbondong-bondong datang untuk "menyembah" dan meminta berkah dari kedua sosok sakti tersebut. Setiap malam Jumat Pon, rata-rata ada sekitar 3000 orang peziarah yang datang untuk meminta berkah di Gunung Kemukus (Suparno, 2017). Terlepas dari obyektifikasi kharisma dari Pangeran Samudro dan Dewi Ontrowulan, banyak para peziarah memanfaatkan Gunung Kemukus sebagai obyek wisata pemuas birahinya. Alhasil, Gunung Kemukus dikenal dengan prostitusi berkedok ritual, karena syarat ritualnya yang mengharuskan berhubungan badan dengan pasangan yang bukan muhrimnya.

\section{Ngalap Berkah di Gunung Kemukus}

Dimensi ritual yang ada di Gunung Kemukus yang "memaksa" adanya hubungan badan dengan yang bukan muhrimnya, membuat para Pekerja Seks Komersial (PSK) mendapat "ladang" baru dalam menjajakan jasanya. Aturan ritual ini merupakan sebuah salah tafsir dari perkataan yang dipercaya sebagai mandat dari Pangeran Samudra, yang bunyinya : "sing sapa duwe panjangka, marang samubarang kang dikarepake bisane kelakon iku, kudu sarono pawitan temen, manteb kanthi ati suci, aja slewing-sleweng, kudu mung mandheng marang kang katuju, cedhakno demene koyo dene yen arep nekani marang panggonane dhemenane". Kata dhemenane yang semula bermakna "kesungguhan", telah bermetamorfosa dan berubah makna menjadi "selingkuhan". Inilah yang menjadi pangkal dari adanya ritual melakukan hubungan badan dengan mencari pasangan yang bukan muhrimnya. Salah tafsir ini, kemudian melegalkan para PSK untuk membantu para peziarah melengkapi ritualnya. Penafsiran versi inilah yang menyebabkan berkembangnya keyakinan, bahwa 
jika ingin sukses dan terkabul semua keinginan di dunia, maka harus berselingkuh seperti yang dilakukan Dewi Ontrowulan dengan Pangeran Samudra.

Fakta adanya ritual seks dalam tradisi ziarah di Gunung Kemukus mencerminkan bahwa perilaku para peziarah Gunung Kemukus menunjukkan tentang ambiguitas dari tujuan praktek mistisisme Jawa. Terdapat kecenderungan bahwa motivasi peziarah dalam melaksanakan praktek asketisme telah menekankan pada kepentingan duniawi semata daripada tujuan untuk "manunggal" dengan Tuhan atau mencari jalan Tuhan. Pada sisi yang lain, adanya kecenderungan untuk memperoleh tujuan duniawi dalam tradisi laku asketisme Jawa tersebut telah mendukung proses kapitalisasi, yang menyebabkan terjadinya proses komodifikasi berbagai praktek ritual ziarah. Meskipun diakui tentang peranannya dalam menumbuhkan perekonomian masyarakat, namun kapitalisasi juga menimbulkan adanya pencerabutan akar kultur dan akar religi di balik praktek ziarah di makan Pangeran Samoedro, Gunung Kemukus (Soehadha, 2013).

Kemasyhuran yang disebabkan erotisme di Gunung Kemukus terus meningkat pada tahun 1980an, seiring dengan dukungan yang diberikan oleh Pemerintah Sragen melalui Dinas Pariwisata yang menjadikannya sebagai salah satu tujuan wisata ziarah. Ritual ngalap berkah yang sebelumnya, kepengurusannya dipegang oleh penduduk Desa setempat, kemudian diambil alih oleh Dinas Pariwisata. Akibatnya, kegiatan ngalap berkah mengalami komodifikasi. Ekspansi pasar pariwisata dan prostitusi menyebabkan kegiatan ritual ngalap berkah yang sebelumnya merupakan bagian dari ekspresi keberagaman asketisme Islam Jawa tersebut, kemudian cenderung dengan semakin mengkukuhkan penyimpangan mitos tentang "ritual seks" sebagai bagian dari tirakat ngalap berkah.

Banyak di antara Pelaku Seks Komersial (PSK) yang telah mulai melaksanakan profesinya tersebut sejak tahun 1980an atau sejak tahun 1990-an, karena motivasi berupa desakan ekonomi, sehingga sebagian dari mereka kemudian menetap dan tinggal sebagai penduduk tetap di Desa Pendem, yang semula mereka adalah berasal dari penduduk pendatang, yang kemudian ada peluang dari segi ekonomi, sehingga membuat mereka menetap di Desa Pendem. Perkembangan kegiatan ritual seks telah ada sejak lama. Perkembangan tentang kegiatan prostitusi secara terbuka baru terjadi mulai awal tahun 1980-an. Perkembangan prosititusi itu tidak semata tentang ritual seks yang menjadi persyaratan ngalap berkah, melainkan juga didorong oleh pariwisata yang telah dikembangkan sejak tahun 1980an (Soehadha, 2013).

\section{Ritual Mistis dalam kontestasi politik}

Tersohornya Gunung Kemukus sebagai tempat keramat yang dapat memberikan berkah terhadap apa saja yang dicita-citakan membuat banyak orang datang untuk ngalap berkah di sana. Cerita yang berkembang di dalam masyarakat tentang "keampuhan" dari Gunung Kemukus yang telah banyak terbukti, membuat banyak orang berkeinginan untuk ikut melaksanakan ritual di sana. Tidak sedikit juga para calon legislatif dan calon pejabat, baik tingkat daerah maupun pusat datang untuk ngalap berkah di Gunung Kemukus. Berdasarkan penuturan pengelola Gunung Kemukus, setiap hari pasaran banyak pejabat, maupun calon peserta pileg (pemilihan legislatif) datang ke tempat tersebut untuk meminta berkah kepada Pangeran Samudra. Bahkan, penuturan selanjutnya mengatakan bahwa pengelola dan pedagang di Gunung Kemukus mendapat "keberkahan" setiap ajang pesta demokrasi, baik untuk pemilihan legislatif, ataupun pemilihan presiden (Pardi, 2018). Hal ini terjadi karena banyak dari kalangan peserta pileg maupun anggota tim sukses datang untuk melakukan ritual di Gunung Kemukus. Menelisik lebih jauh, ritual yang dilakukan oleh peserta kontestasi politik tersebut dipercaya dapat memuluskan apa yang dicita-citakan. Secara faktual apa yang dipercaya tersebut dapat dikelompokan sebagai berikut :

\section{Membangun Harmonisasi antara Makrokosmos dan Mikrokosmos}

Di alam pikir dunia Jawa, atau masyarakat tradisional pada umumnya, harmonisasi antara makrokosmos dan mikrokosmos sangat dipercaya akan berdampak di dalam kehidupannya. Apabila 
terjadi kekacauan di alam gaib, maka di alam nyata juga akan mengalami kekacauan. Dari alam pikir yang demikian, peserta kontestasi politik berusaha mendapatkan "restu" terlebih dahulu di alam gaib. Apabila alam gaib sudah merestui, maka mereka akan mengalami kemudahan untuk berjuang di dalam nyata. Kepercayaan itulah yang melandasi banyak peserta kontestasi politik ngalap berkah di sana. Bila hari pasaran tiba, akan terlihat mobil berplat merah terparkir di sana. Pada sisi yang lain, akan tampak deretan mobil yang biasa hanya dimiliki oleh masyarakat kelas menengah ke atas. Warga setempat mengisahkan, bahwa pemilik mobil-mobil tersebut merupakan pengusaha dan pejabat yang hendak ngalap berkah dengan Pangeran Samudra. Di sela-sela seusai bersembayang di petilasan Pangeran Samudra, ada seseorang yang disertai dengan rombongan masuk ke dalam warung dan juga di dalamnya terdapat penginapan, sosok tersebut adalah calon wakil rakyat di Dapil Jawa Tengah 1. Beliau menuturkan, bahwa untuk memenangkan kontestasi pileg di Jawa Tengah, perlu meminta ijin kepada "penguasa" di wilayah tersebut. Salah satu yang dipercaya dapat membantu adalah Pangeran Samudro. Kulonuwun dengan "penguasa" alam gaib, membuat kenyataan menjadi wakil rakyat semakin mendekat. Harmonisasi antara alam gaib (makrokosmos) dengan alam nyata (mikrokosmos) perlu dilakukan, supaya tidak terjadi kekacauan. Apabila alam gaib merestui, maka alam nyata menjadi mudah dijalani.

\section{Mendapat Kharisma sebagai pemimpin}

Salah satu yang dicari dari sebuah kepemimpinan adalah kharisma. Orang yang berkharisma dapat dengan mudah menarik hati orang untuk mengikutinya. Apabila menilik pemikiran Max Weber, dalam kepimpinan kekuasaan dan wewenang sangat berbeda. Weber berpendapat bahwa kekuasaan merupakan kemampuan untuk memengaruhi pihak lain menurut kehendak dari sang pemegang kekuasaan. Dalam menjalankan kekuasaannya, tindak kekerasan menjadi legal ketika dipakai untuk "memaksa" pengikutnya supaya menuruti kehendaknya. Di sisi yang lain, kewenangan merupakan dukungan yang diberikan kepada seseorang baik dari kelompok, rakyat ataupun penguasa. Weber membagi kewenangan dalam beberapa bentuk yaitu, wewenang kharismatik, wewenang tradisional dan wewenang rasional atau legal. Wewenang kharismatik adalah kemampuan khusus yang sifatnya pemberian dari Tuhan yang Maha Kuasa. Dalam alam pikir politik modern, kekuasaan harus disertai dengan wewenang. Tanpa wewenang, kekuasaan tidak dapat berjalan dengan baik.

Wewenang kharismatik inilah yang ada dan dipercaya oleh para peserta kontestasi politik untuk dicari dari "penguasa" alam ini. Banyak peserta kontestasi politik berusaha mendapatkan kharisma dengan melakukan ritual di Gunung Kemukus. Mereka percaya bahwa dengan melakukan ritual ngalap berkah ke Pangeran Samudra, kharisma akan diturunkan kepadanya. Juru kunci makam Pangeran Samudra menegaskan bahwa beberapa dari pejabat yang sekarang menduduki jabatan Kepala Daerah, ataupun wakil rakyat memulai karirnya dengan melakukan ritual di Gunung Kemukus. Setiap malam satu suro, banyak dari pejabat yang telah berhasil memberikan sumbangan untuk melakukan tirakatan di Gunung Kemukus, dengan pertunjukan wayang, ataupun tradisi brokohan (makan bersama dengan nasi tumpeng). Perburuan kharisma inilah yang membuat para politisi melakukan ritual ngalap berkah di Gunung Kemukus.

\section{Mendapat pulung (kebegjan)}

Dalam konsep Jawa, orang yang mendapat pulung pasti akan menjadi orang besar, baik itu raja, ataupun pejabat penting lainnya. Alam pikir yang seperti ini yang kemudian dicari oleh orang-orang yang ingin menjadi orang besar. Kedigdayaan Gunung Kemukus yang dapat merestui orang yang melakukan ritual di sana membuat pengunjung selalu ramai berduyun-duyun ke sana. Para peserta kontestasi politik berusaha mendapatkan pulung dengan melakukan ritual ngalap berkah di sana. Melalui ritual tersebut, mereka percaya bahwa Pangeran Samudra akan memberikan pulung (keberuntungan) kepada mereka yang dikenannya. Hal inilah yang membuat setiap pesta demokrasi terjadi di Indonesia, Gunung Kemukus selalu ramai dikunjungi oleh pesertanya. 


\section{Memohon hikmat dan belas kasihan}

Salah satu yang menjadi pemicu untuk melakukan ritual di Gunung Kemukus adalah meminta hikmat dari penguasa alam semesta. Mereka percaya bahwa Pangeran Samudra merupakan salah satu penguasa alam semesta, sehingga hikmat yang diberikan oleh Pangeran Samudra sangat bermanfaat dalam membantunya dalam pemenangan kontestasi politik. Belas kasihan dan hikmat dari Pangeran Samudra dipercaya ampuh dalam memenangkan "pertarungannya", terbukti bahwa banyak pejabat yang lahir dari ritual ngalap berkah di Gunung Kemukus.

\section{Simpulan}

Secara faktual, ritual mistis masih diyakini dan dilakukan oleh masyarakat di era modern. Di era kontestasi politik, ritual mistis jadi laris dilakukan oleh peserta kontestasi politik. Gunung Kemukus salah satu yang laris didatangi untuk ritual menjelang pesta demokrasi. Paradigma agama tradisional, dalam hal ini agama Jawa yang menjadi pemandu dalam melakukan ritual tersebut. Para peserta kontestasi politik ini menyakini bahwa melalui ritual mistis mereka mendapatkan harmonisasi antara makrokosmos dan mikrokosmos, kharisma sebagai pemimpin, mendapat pulung (kebegjan), serta mendapatkan hikmat dan belas kasihan dari Pangeran Samudra. Ritual mistis tersebut dipercaya dapat efektif sebagai jalan untuk memenangi kontestasi di dunia politik.

\section{Referensi}

Ahmad. (2017). Wawancara Dengan Kepala Biro Pariwisata Kab. Sragen.

Anderson, B. R. O. (1984). Gagasan Kekuasaan Dalam Budaya Jawa. Penerbit Sinar Harapan.

Aribowo, P. (2017). Wawancara Kepada Dinas Pariwisata Jawa Tengah.

Bedjo. (2017). Wawancara dengan Peziarah Gunung Kemukus.

Endraswara, S. (2003). Mistik Kejawen: Sinkretisme, Simbolisme dan Sufisme dalam Budaya Spiritual Jawa. Narasi.

Endraswara, S. (2011). Kebatinan Jawa. Lembu Jawa.

Endraswara, S. (2015a). Agama Jawa. Narasi.

Endraswara, S. (2015b). Falsafah Hidup Jawa. Cakrawala.

Furseth. (2006). an Introduction to the Sociology of Religion. Ashgate Publishing Limited.

Lorens, B. (2000). Kamus Filsafat. Gramedia.

Mujiyah, N. (2014). Islam dan Budaya Lokal: Studi Etnografi Tentang Pitungan Boyongan Rumah Menurut Mbah Miran Di Dusun Klaci Jombang. UIN Sunan Ampel Surabaya.

Novitasari, R. D. (2015). Ritual Ziarah Makam Pangeran Samudro Di Gunung Kemukus Desa Pendem Kecamatan Sumberlawang Kabupaten Sragen. Universitas Negeri Semarang.

Oktiasasi, A. W., \& Harianto, S. (2016). Perhitungan Hari Baik dalam Pernikahan. Jurnal Paradigma, 4(3).

Pardi. (2018). Wawancara Dengan Bapak Pardi.

Permatasari, B. F., \& Habsari, N. T. (2015). Persepsi Masyarakat Desa Jiwan Terhadap Kalender Jawa Dalam Membangun Rumah. Agastya: Jurnal Sejarah Dan Pembelajarannya, 5(01), 165-182.

Ricklefs, M. (2004). Sejarah Indonesia Modern. Serambi.

Sari, Indah Ambar; Azhar, M. A. (2016). Mitos dan Kekuasaan Studi Kasus Hegemoni Ngalap Berkah Gunung Kemukus Terhadap Pencarian Kekuasaan. EJurnal Politika, 1(1), 1-13.

Setiawati, R., \& Kuswarno, E. (2016). Meaning construction of "ngalap berkah" ritual in mountain kemukus of central Java in Indonesia: An interpretation from a communication perspective. Man in India, 96(11), 47494764 .

Setiawati, R., \& Safitri, K. A. (2018). Bahasa Pada Komunikasi Ritual Ziarah Ngalap Berkah Di Kawasan Wisata Gunung Kemukus Sragen Jawa Tengah. Jurnal Sosial Humaniora Terapan, 1(7), 21-31.

Siatawati, R., \& Priyanto. (2015). Komunikasi Ritual Peziarah “Ngalap Berkah” Di Kawasan Wisata Gunung Kemukus. Vokasi Indonesia, 3(2), 74-84. https://doi.org/10.1007/82

Soehadha, M. (2013). Komodifikasi Asketisme Islam Jawa: Ekspansi Pasar Pariwisata dan Prostitusi di Balik Tradisi Ziarah di Gunung Kemukus. Harmoni, 12(1), 101-115.

Subagyo; Muridjal, A. I. (2013). Fenomenologi Ziarah Makam Gunung Kemukus. Jurnal Komunikasi Massa, 6(2), 221-234.

Sugiyono. (2012). Memahami Penelitian Kualitatif. Alfabeta.

Sularno, M. R. P. \&. (2017). Motivasi Ziarah Di Makam Pangeran Samudra Gunung Kemukusdan Mitosritual 
Hubungan Seks. In Teori Hukum Islam dan Multikulrulisme. Pustaka Tebu Ireng. Sumardjo, J. (2011). Sunda Pola Rasionalitas Budaya. Kelir.

Suparno. (2017). Wawancara Ketua RT 2 Desa Pendem.

Weber, M. (1978). Economy And Society. Volume I. (1910-14). An Outline of Interpretive Sociology (C. Roth, Guenther; Wittich (ed.)). The Regents of University of California.

Yeshe, L. T. (2001). Introduction to Tantra:The Transformation of Desire. Wisdom Publication.

Yuliana, \& Sadewo, F. S. (2019). Rasionalitas Menghitung Weton Pada Pernikahan Pasutri Berpendidikan Tinggi. Paradigma, 7(2), 1-6.

(C) 2020 by the authors. Submitted for possible open access publication under the terms and conditions of the Creative Commons Attribution 4.0 International (CC BY 4.0) license (https://creativecommons.org/licenses/by/4.0/). 